\title{
Baseline Impact Assessment Studies on Flora \& Fauna around Goa Industrial Development Corporation (GIDC), Goa Zone
}

\author{
${ }^{\mathrm{D}}$ Devarkar V D, ${ }^{2}$ Nichat V V, 3 Joshi M P \\ 'Department of Botany, SCS College, Omerga \\ 2Department of Zoology, SCS College, Omerga \\ ${ }^{3}$ Director, Surya Envirotech, Hanuman Nagar, Nagpur \\ Corresponding Author: milindjoshi70@gmail.com
}

\section{Manuscript Details}

Manuscript Submitted : 12/04/2018

Manuscript Accepted : 16/04/2018

Manuscript Published : 15/05/2018

\section{Available On}

https://plantaescientia.website/ojs/

\section{Cite This Article As}

Devarkar V D, Nicaht VV \& M P Joshi, 2018.

Baseline Impact Assessment Studies on Flora o

Fauna around Goa Industrial Development

Corporation (GIDC), Goa Zone, Pla. Sci. 2018;

Vol. 01 Issue 01: 09-17. Doi :

https://doi.org/10.32439/ps.vli01.9-17

\section{Copyright}

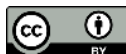

(c) The Author (s). 2018 Open Access This article is distributed under the terms of the Creative Commons Attribution 4.0 International License http://creativecommons.org/licenses/by/4.0/

$\underline{\text { Indexed In }}$

Crossref, Google Scholar, Index Copernicus International (ICI), Directory of Research Journal Indexing (DRJI)

\begin{abstract}
This study projected for environmental impact driven by the pharmaceutical activity on regional biological environment quality. This Environmental Impact Assessment (EIA) study based on one season primary environmental quality data, environmental impact statement based on the identification, prediction, and evaluation of impact. Detailed studies were carried out about biological components of the environment in the study area of 7 $\mathrm{km}$ radial distance from Usgaon as a central point. The paper is dealing with, Study of the biological environment includes the topography, the vegetation type and the flora and fauna of the region along with crops for prediction of impacts due to the existing pharmaceutical effluents and bulk drugs at Marvasodo, Usgaon, and Phonda (Goa).
\end{abstract}

Keywords: Biological Environment, Impact Assessment, Goa 


\section{INTRODUCTION}

The Indian Pharmaceutical Industry today is in the front rank of India's science-based industries with wide ranging capabilities in the complex field of drug manufacture and technology (Kumar \& Sharan, 2013). A highly organized sector, the Indian Pharma Industry is estimated to be worth $\$ 4.5$ billion, growing at about 8 to 9 percent annually. It ranks very high in the third world, in terms of technology, quality, and range of medicines manufactured. The Indian Pharmaceutical sector is highly fragmented with more than 20,000 registered units. It has expanded drastically in the last two decades. The leading 250 pharmaceutical companies control $70 \%$ of the market with market leader holding nearly $7 \%$ of the market share. It is an extremely fragmented market with severe price competition and government price control. (WPI; WP3WP5)

Thus, every leading pharma company wants to retain its share in the Indian market and therefore, companies are expanding their production limits day by day. Due to this activity, there is tremendous pressure on the surrounding environmental components such as air, water, soil, flora, fauna and noise levels. This is an attempt to study the ground truth and predict the possible impact of such activities on environmental components as compared to the standards mentioned by the Pollution Control Board in India.

\section{STUDY AREA}

The study area comes in the major gaps in the range of mountain of Sahyadri, known as Goa gap between the Maharashtra and Karnataka sections. Goa Industrial Development Corporation (Fig.l) is the most favorite site for the development and expansion of the pharma unit due to flourishing Trading Culture and excellent Port services at Mormugao - a major, modern and thriving port, the highest exporter in the country. Study site Panjim is located at longitude $15^{\circ} 3^{\prime} \mathrm{N}$ and latitude $73^{\circ} 55^{\prime} \mathrm{E}$. (WP2). The study area was limited to $7 \mathrm{~km}$ radial distance from the proposed plant site (Fig.2). The identified impact zone is covered by agricultural land, forest, wasteland, marketplaces, and other rurally inhabited localities. Within the study area, there are some other big and small industries. Mining, stone quarrying, and crushing are the major activities in the study area. Viz. Merk Pvt. Ltd., Finolex cables Ltd, Heing India Pvt Ltd., Marico Ltd, Madras Rubber Factory, Nestle India Ltd, Sanjivani Sahakar Sakhar Karkhana Ltd, Goa Meet Complex, Hindustan Foods Ltd $\&$ Goa Cattle Feed are the industry prevalent in the area.

\section{METHODOLOGY}

The reconnaissance survey was undertaken within the study area to collect information regarding the topography of the study area, and other features relevant

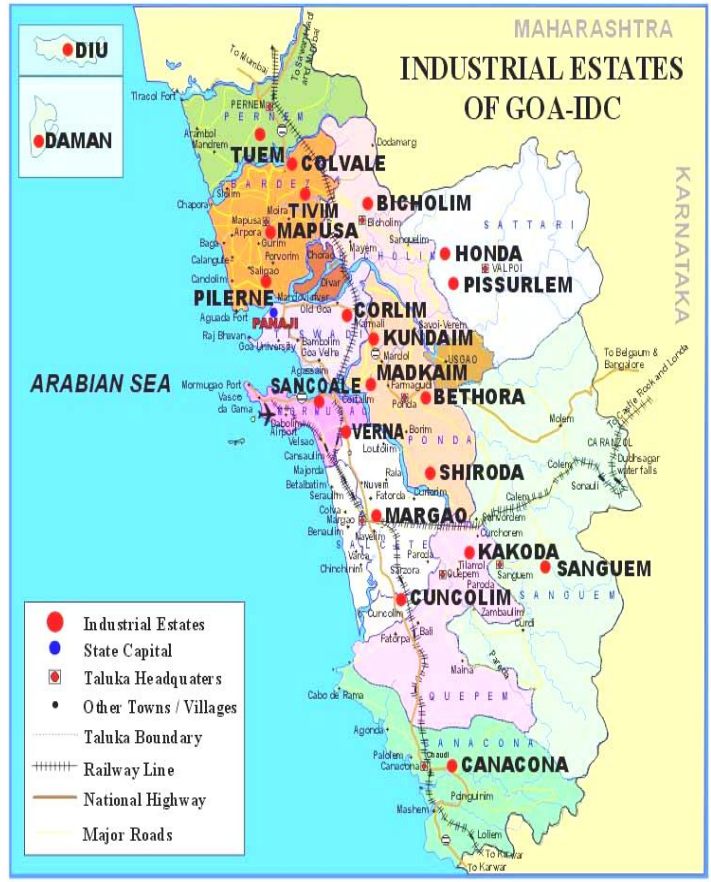

Fig.l: Study Area Map (Courtesyhttp://www.goaidc.com)

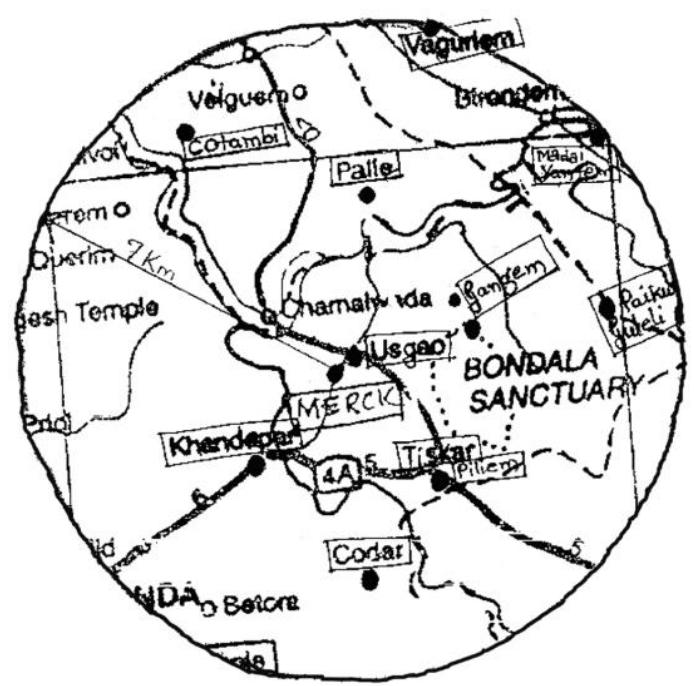

Fig. 2: Study Area (7 Kms radius from Usgaon)

to the flora and fauna. The study was conducted for the summer season (February 2007 - March 2008). Secondary data collection from various government departments and NGOs were collected to know the past and present status of the various components under study. First hand on-site information and data collection done by authors compared with the standard values for analyzing the impacts.

Identification of the collected plant specimens was made with the help of Standard Floras (Gamble, 1919; Hooker, 1872-1897; Mukherjee, 1984; Almeida, 1990; Naik, 1998; Sharma et al, 1996; Singh \& Karthikeyan, 2000). Soil microflora plays an important role as soli quality depends 
upon the population of Bacteria, Fungi, and Actinomycetes which are vital components of the land environment. The microbial samples collected from various locations in the study area were observed with Compound Research Microscope in the laboratory. Identification of sampling locations was done for the study on biological environment based on topography, vegetation structure, pattern, and distribution. The details of sampling locations are presented in Table 1.

Table 1: Sampling Locations for Plants Identification

\begin{tabular}{|c|l|}
\hline Sr. No. & Name of the Villages \\
\hline 1. & Bondla a \\
\hline 2. & Bondla $\mathrm{b}$ \\
\hline 3. & Bondla c \\
\hline 4. & Bondla d \\
\hline 5. & Paikul \\
\hline 6. & Guleli \\
\hline 7. & Ganjem \\
\hline 8. & Guleli Irrigation \\
\hline 9. & Usgao \\
\hline 10. & Candepar \\
\hline 11. & Tiskar \\
\hline 12. & Piliem \\
\hline 13. & Codar \\
\hline 14. & Candepar OPA \\
\hline 15. & Vagurmem \\
\hline 16. & Candepar Curti \\
\hline
\end{tabular}

Typical land use pattern in Goa state is mentioned in the graph (WP2). The structure and composition of vegetation cover in the phyto-sociological association were studied by the quadrate method adopted by Clements (1960). In the study of a vegetation community, quadrates equivalent to one hectare (100x100 Sq.m.) for trees; the quadrates of smaller sizes (20x20 sq.m.) for shrubs and quadrates of smallest size ( $5 \times 5$ Sq.m.) for grassland/low herbaceous community were used for the study. To characterize the community as a whole, certain parameters are used. The parameters like Frequency, Density, Importance Value Index (IVI) and Simpson's Diversity Index (SDI) were used in quantitative analysis of plant community. Average density of plants per hectare is shoe in Fig. 3 and Land use pattern is shown in Fig. 4. The formulae incorporating different parameters analyzed and assessed for obtaining the Baseline Terrestrial Environmental Status are presented in Table 2.

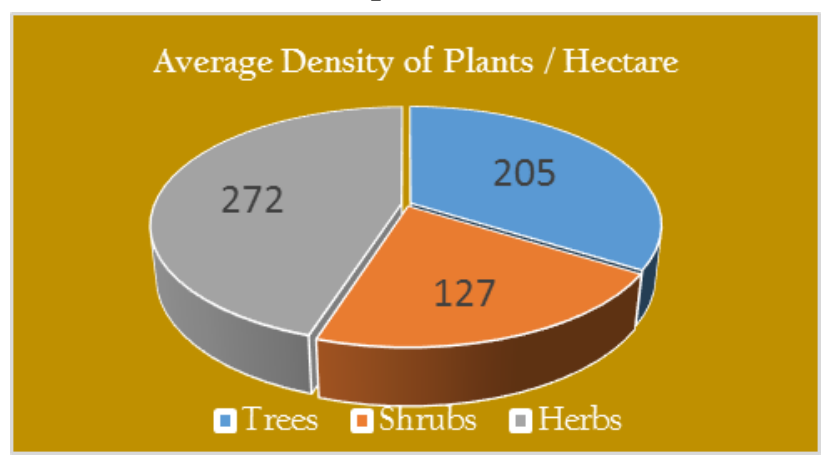

Table 2: The formulae Used to study Baseline Terrestrial Environmental Status

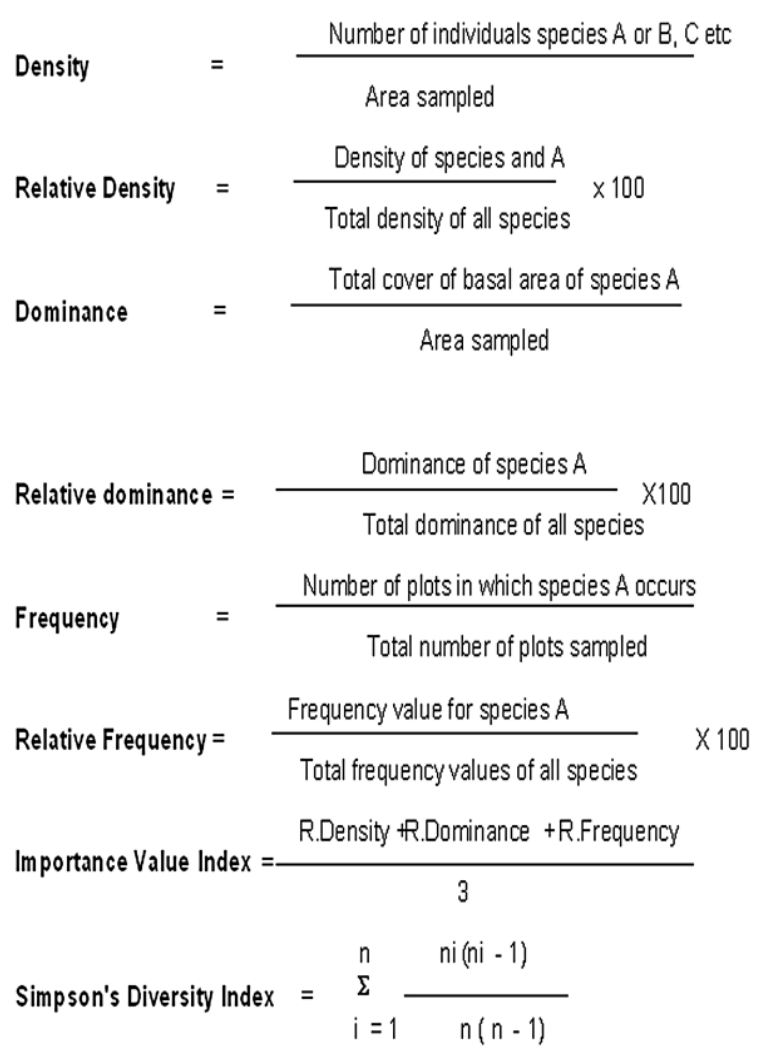

$\mathrm{ni}$ - is the number of individuals of thie species in the sample and

$\mathrm{n}$ - is the total number of individuals in the sample.

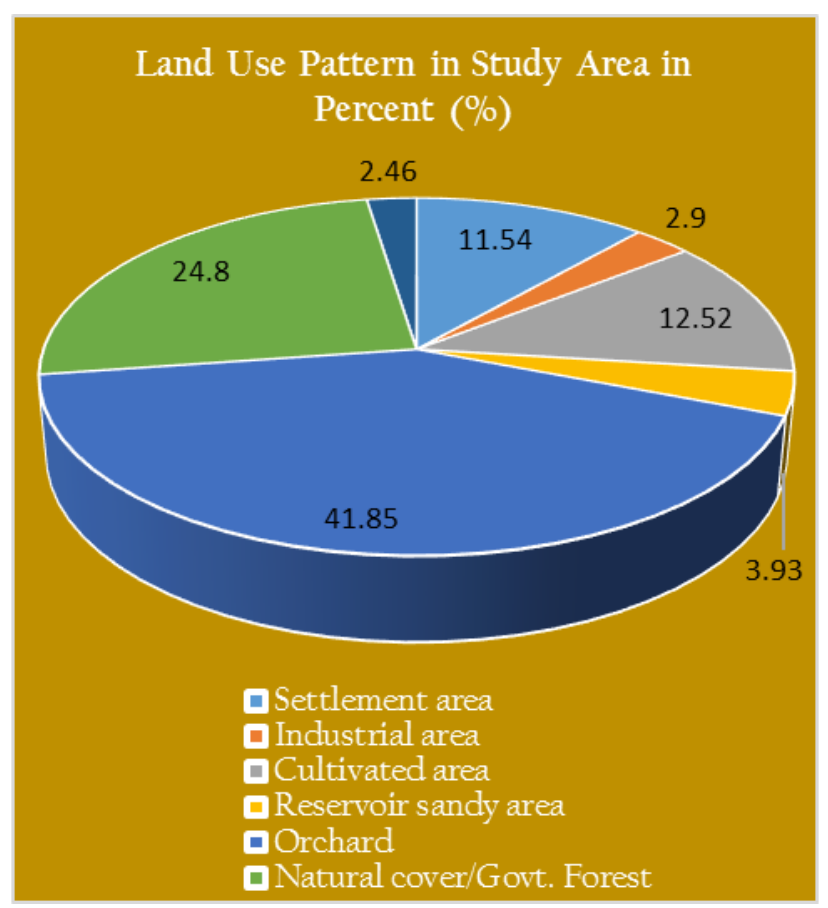

Fig.4 : Land use and Land Cover in Study Area 
Actual counts method of the animals is used by following the census technique. At each station, a walkthrough census of animals is made. Line transects of $\mathrm{lkm}$ selected for the study and covered by walking. Numbers of animal species were counted directly. Bird fauna was observed through binoculars. Standard field identification guides were used for identifying animal species.

Local fishermen were interviewed for the impact of the effluent discharge on the Fishes. Identification of fishes is done with standard manuals. Fish catch analysis was done with the help of Experts present at National Institute of Oceanography, Goa. The fisherman population is estimated about 24,051 out of which 5,258 are active fisherman in the district (WP2).

\section{OBSERVATIONS \& RESULTS}

The changes in a biotic community are studied in the pattern of distribution, abundance, and diversity. The reconnaissance revealed that the land around project site is covered with vegetation developed by surrounding pharmaceutical industries. Anacardium, occidentale (Kaju), Cocos nucifera (Coconut), Mangifera indica (Mango) are observed to be dominant along the roadside and species of Avicennia, Rhizophora, Brugueria, Kandellia, Sonneratia near the seashore.

The coast is silty to clayey silt substratum with some sandy part. The major riverine planes in Goa are those of the Mandavi and Zuari which, together constitutes a major alluvial embayment.

\section{Floral Diversity}

List of plants dominants in the region is prepared based on visual observation during site visits. Data available with various agencies is referred for identifying rare or endangered species in the region. The wasteland is the areas without any productive usage but left wild with growth of vegetation in natural state. The plants growing are Grewia spp, Woodfordia spp. Vitex spp. Adhatoda spp. Calotropis procera, etc. along with wide variety of herb and shrub species.

During the floristic survey, a total of 110 plant species comprising 55 trees, 35 shrubs and 20 herb species were recorded from the study area belonging to 45 families. The list of the plant species (trees, shrubs and herbs) are shown in Table 4

\begin{tabular}{|c|c|c|c|}
\hline $\begin{array}{l}\text { Sr. } \\
\text { No }\end{array}$ & Botanical name & Habit & Family \\
\hline 1. & Crossandra undulifolia & $\mathrm{S}$ & Acanthaceae \\
\hline 2. & Adhatoda vasica & S & Acanthaceae \\
\hline 3. & Ammania baccifera & $\mathrm{H}$ & Scrophulariaceae \\
\hline 4. & Spillanthus acmella & $\mathrm{H}$ & Asteraceae \\
\hline 5. & Cuscutta reflexa & $\mathrm{H}$ & Convolvulaceae \\
\hline 6. & Spondisis oinnata & $\mathrm{T}$ & Rubiaceae \\
\hline 7. & Cayrtia carnosa & $\mathrm{T}$ & Vitaceae \\
\hline 8. & Mangifera indica & $\mathrm{T}$ & Anacardiaceae \\
\hline 9. & Alangis lamarokki & S & Clusiaceae \\
\hline 10. & Kaeampfria rotunda & $S$ & Clusiaceae \\
\hline 11. & Bauhinia racemosa & $\mathrm{T}$ & Caesalpiniaceae \\
\hline 12. & Cassia sophora & $\mathrm{T}$ & Caesalpiniaceae \\
\hline 13. & Cassia auriculata & $\mathrm{S}$ & Caesalpiniaceae \\
\hline 14. & Acacia arabica & $\mathrm{T}$ & Mimosaceae \\
\hline 15. & Artocarpus hirsute & $\mathrm{T}$ & Artocarpaceae \\
\hline 16. & Cassia fistula & $\mathrm{T}$ & Caesalpiniaceae \\
\hline 17. & Ipomoea biloba & S & Convolvulaceae \\
\hline 18. & Ipomoea muricata & S & Convolvulaceae \\
\hline 19. & Morinda citrifolia & $\mathrm{T}$ & Morindaceae \\
\hline 20. & Jasminum sambac & $\mathrm{S}$ & Apocyanaceae \\
\hline 21. & Adansonia digitada & $\mathrm{T}$ & Malvaceae \\
\hline 22. & Terminalia bellerica & $\mathrm{T}$ & Combretaceae \\
\hline 23. & Aegle marmelos & $\mathrm{T}$ & Rutaceae \\
\hline 24. & Grewia orientalis & $S$ & Tiliaceae \\
\hline 25. & Sterculia balanghas & $\mathrm{T}$ & Sterculiaceae \\
\hline 26. & Terminalia catappa & $\mathrm{T}$ & Combretaceae \\
\hline 27. & Mallotus philippensis & $\mathrm{T}$ & Euphorbiaceae \\
\hline 28. & Amaranthus spinosus & $\mathrm{H}$ & Amaranthaceae \\
\hline 29. & Amaranthus viridis & $\mathrm{H}$ & Amaranthaceae \\
\hline 30. & Cissampelos pareira & $\mathrm{S}$ & Menispermaceae \\
\hline 31. & $\begin{array}{l}\text { Syzygium } \\
\text { Caryophyllatum }\end{array}$ & $\mathrm{T}$ & Myrtaceae \\
\hline 32. & Thespecia populnea & $\mathrm{T}$ & Malvaceae \\
\hline 33. & Acacia latronum & $\mathrm{T}$ & Mimosaceae \\
\hline 34. & Ipomoea digitata & $\mathrm{S}$ & Convolvulaceae \\
\hline 35. & Ocimum basilicum & $S$ & Lamiaceae \\
\hline 36. & Semecarpus anacardium & $\mathrm{T}$ & Anacardiaceae \\
\hline 37. & Averrhoa bilimbi & $S$ & Rutaceae \\
\hline 38. & Flacourtia montana & $\mathrm{T}$ & Flacourtiaceae \\
\hline 39. & Dioscorea alata & S & Dioscoreaceae \\
\hline 40. & Jatropha multifida & S & Euphorbiaceae \\
\hline 41. & Acacia intasia & $\mathrm{T}$ & Mimosaceae \\
\hline 42. & Punica gramatum & $\mathrm{T}$ & Punicaecae \\
\hline 43. & Ficus gibbosa & $\mathrm{T}$ & Moraceae \\
\hline 44. & Bauhinia purpurea & $\mathrm{T}$ & Caesalpiniaceae \\
\hline 45. & Crotalaria jипсеа & $\mathrm{H}$ & Fabaceae \\
\hline
\end{tabular}




\begin{tabular}{|c|c|c|c|}
\hline 46. & Anogeissus latifolia & $\mathrm{T}$ & Fabaceae \\
\hline 47. & Synsyzigium zeylanicum & $\mathrm{T}$ & Myrtaceae \\
\hline 48. & Ficus microcarpa & $\mathrm{T}$ & Moraceae \\
\hline 49. & Nerium indicum & $\mathrm{T}$ & Apocyanaceae \\
\hline 50. & Ixora barota & S & Verbenaceae \\
\hline 51. & Bauhinia tomentosa & $\mathrm{T}$ & Caesalpiniaceae \\
\hline 52. & $\begin{array}{l}\text { Holarrhena } \\
\text { antidysenterica }\end{array}$ & $\mathrm{T}$ & Apocyanaceae \\
\hline 53. & Woodfordia fruticosa & S & Malvaceae \\
\hline 54. & Vateveria indica & $\mathrm{H}$ & Poaceae \\
\hline 55. & Hiptage benghalensis & $\mathrm{H}$ & Bignoniaceae \\
\hline 56. & Withania Somnifera & $\mathrm{H}$ & Solanaceae \\
\hline 57. & Solanum indicum & S & Solanaceae \\
\hline 58. & Ricinus communis & S & Euphorbiaceae \\
\hline 59. & Jatropha curcas & $\mathrm{T}$ & Euphorbiaceae \\
\hline 60. & Pithacellolum dulce & $\mathrm{T}$ & Mimosaceae \\
\hline 61. & Melia azaedirach & $\mathrm{T}$ & Meliaceae \\
\hline 62. & Flacouritia latifolia & $\mathrm{T}$ & Flacourtiaceae \\
\hline 63. & Elephantopus scaber & $\mathrm{H}$ & Asteraceae \\
\hline 64. & Borreria hispida & $\mathrm{H}$ & Boraginaceae \\
\hline 65. & Cayratia pedata & $\mathrm{T}$ & Vitaceae \\
\hline 66. & Adiantum lunulatum & $\mathrm{H}$ & Adiantaceae \\
\hline 67. & Portulaca oleracea & $\mathrm{H}$ & Portulacaceae \\
\hline 68. & Terminalia bellerica & $\mathrm{T}$ & Combretaceae \\
\hline 69. & Cayratia trifolia & S & Vitaceae \\
\hline 70. & Terminalia bellerica & $\mathrm{T}$ & Combretaceae \\
\hline 71. & Tinospora cordifolia & S & Menispermaceae \\
\hline 72. & Terminalia chubula & $\mathrm{T}$ & Combretaceae \\
\hline 73. & Jasminum suriculatum & S & Apocyanaceae \\
\hline 74. & Hardwickia binata & $\mathrm{T}$ & Balanitaceae \\
\hline 75. & Lagerstrosmia indica & $\mathrm{T}$ & Lythraceae \\
\hline 76. & Murraya Koenigii & S & Rutaceae \\
\hline 77. & Strychnos nuxvomica & S & Liliaceae \\
\hline 78. & Bambusa arundinacea & S & Poaceae \\
\hline 79. & Asteracantha longifolia & $\mathrm{H}$ & Acanthaceae \\
\hline 80. & Celastrus paniculatus & S & Celastraceaeae \\
\hline 81. & Sterculia urens & $\mathrm{T}$ & Sterculiaceae \\
\hline 82. & Diescorea esculenta & S & Dioscoreaceae \\
\hline 83. & Kydia calicina & $\mathrm{T}$ & Malvaceae \\
\hline 84. & Pongamia pinnata & $\mathrm{T}$ & Fabaceae \\
\hline 85. & Averrohea carambola & S & Rutaceae \\
\hline 86. & $\begin{array}{l}\text { Ptrerospermum } \\
\text { acerifolium }\end{array}$ & $\mathrm{T}$ & Combretaceae \\
\hline 87. & Dioscorea hispida & S & Dioscoreaceae \\
\hline 88. & Solanum surattense & $\mathrm{H}$ & Solanaceae \\
\hline 89. & Sterculia colorata & $\mathrm{T}$ & Sterculiaceae \\
\hline 90. & Magnolia gtandiflora & $\mathrm{T}$ & Magnoliaceae \\
\hline
\end{tabular}

\begin{tabular}{|l|l|c|l|}
\hline 91. & Saraka indica & T & Anacardiaceae \\
\hline 92. & Musa sapientum & H & Musaceae \\
\hline 93. & Terminalia paniculata & T & Combretaceae \\
\hline 94. & Helictares isora & T & Tiliaceae \\
\hline 95. & Dioscorea pentaphylla & S & Dioscoreaceae \\
\hline 96. & Barleria prionitis & S & Acanthaceae \\
\hline 97. & Alternanthera sesillis & H & Amaranthaceae \\
\hline 98. & Dendrocalamus strictus & T & Poaceae \\
\hline 99. & Curculigo orchioidos & H & Hypoxidaceae \\
\hline 100. & Citrus medica & T & Rutaceae \\
\hline 101. & Dolichandrone falcata & S & Sapindaceae \\
\hline 102. & Cissus quadrangularis & T & Vitaceae \\
\hline 103. & Indigefera tinctoria & H & Fabaceae \\
\hline 104. & Cymbopogon citratus & H & Poaceae \\
\hline 105. & Lawsonia inermis & T & Lythraceae \\
\hline 106. & Vitex altissima & S & Verbenaceae \\
\hline 107. & Cocos nucifera & T & Arecaceae \\
\hline 108. & Areca catechu & T & Arecaceae \\
\hline 109. & Piper longum & S & Piperaceae \\
\hline 110. & Phoenix dactilifera & T & Arecaceae \\
\hline & & & \\
\hline
\end{tabular}

Dominant families of plants recorded in the study area are Combretaceae and Caesalpiniaceae and Acanthaceae.

Simpson's Diversity Index of plants in the study area is based on the total number of individuals of different species to the total number of all species. The Simpson's Diversity Index for herb, shrub, and trees is shown that the area has a low diversity of herbs $(0.025)>$ shrubs > $(0.116)>$ trees (0.176).

The percentage of medicinal plant species for particularly these observations is about $45 \%$. Medicinal plants are divided into three categories on the basis of their trade and local use with high, moderate and low medicinal values as presented in Table 5 .

Natural forests do exist in the area surrounding the project site. However, forest cover on the south-east side has been damaged due to destructive activities. The area of Bondla Wildlife Sanctuary falls in the study area.

Sparse to the dense growth of mangroves are seen in the muddy creeks off coastal belts of the Goa. The present area of survey along the stretch of coast showed the presence of mangrove species viz. Avicennia marina var. marina, Rhizophora, Bruguria spp. Acanthus ilicifolius and Salicornia brachiata. 
Table 5

Medicinal plants growing in the Study Area

\begin{tabular}{|c|c|c|c|}
\hline $\begin{array}{l}\text { Sr. } \\
\text { No }\end{array}$ & Botanical name & Habit & $\begin{array}{l}\text { Medicinal } \\
\text { Value }\end{array}$ \\
\hline 1 & Crossandra undulifolia & S & M \\
\hline 2 & Adhatoda vasica & S & $\mathrm{H}$ \\
\hline 3 & Spillanthus acmella & $\mathrm{H}$ & $\mathrm{H}$ \\
\hline 4 & Acacia Arabica & $\mathrm{T}$ & $\mathrm{H}$ \\
\hline 5 & Cassia fistula & $\mathrm{T}$ & $\mathrm{H}$ \\
\hline 6 & Morinda citrifolia & $\mathrm{T}$ & $\mathrm{H}$ \\
\hline 7 & Terminalia bellerica & $\mathrm{T}$ & $\mathrm{H}$ \\
\hline 8 & Aegle marmelos & $\mathrm{T}$ & $\mathrm{H}$ \\
\hline 9 & Ocimum basilicum & S & $\mathrm{H}$ \\
\hline 10 & $\begin{array}{l}\text { Holarrhena } \\
\text { antidysenterica }\end{array}$ & $\mathrm{T}$ & $\mathrm{H}$ \\
\hline 11 & Withania somnifera & $\mathrm{H}$ & $\mathrm{H}$ \\
\hline 12 & Terminalla bellerica & $\mathrm{T}$ & $\mathrm{H}$ \\
\hline 13 & Tinospora cordifolia & S & $\mathrm{H}$ \\
\hline 14 & Strychnos nuxvomica & S & $\mathrm{H}$ \\
\hline 15 & Asteracantha longifolia & $\mathrm{H}$ & $\mathrm{H}$ \\
\hline 16 & $\begin{array}{l}\text { Ptrerospermum } \\
\text { acerifolium }\end{array}$ & $\mathrm{T}$ & $\mathrm{H}$ \\
\hline 17 & Helictares isora & $\mathrm{T}$ & $\mathrm{H}$ \\
\hline 18 & Barleria prionitis & $S$ & $\mathrm{H}$ \\
\hline 19 & Cuscutta reflexa & $\mathrm{H}$ & L \\
\hline 20 & Cissampelos pareira & S & L \\
\hline 21 & Solanum indicum & S & $\mathrm{L}$ \\
\hline 22 & Terminalia chubula & $\mathrm{T}$ & L \\
\hline 23 & Murraya koenigii & S & L \\
\hline 24 & Saraka indica & $\mathrm{T}$ & L \\
\hline 25 & Lawsonia inermis & $\mathrm{T}$ & L \\
\hline 26 & Bauhinia racemosa & $\mathrm{T}$ & M \\
\hline 27 & Cassia sophora & $\mathrm{T}$ & M \\
\hline 28 & Mallotus philippensis & $\mathrm{T}$ & M \\
\hline 29 & Semecarpus anacardium & $\mathrm{T}$ & M \\
\hline 30 & Averrhoa bilimbi & S & M \\
\hline 31 & Bauhinia purpurea & $\mathrm{T}$ & M \\
\hline 32 & Bauhinia tomentosa & $\mathrm{T}$ & M \\
\hline 33 & Ricinus communis & S & M \\
\hline 34 & Adiantum lunulatum & $\mathrm{H}$ & M \\
\hline 35 & Celastrus paniculatus & S & $\mathrm{M}$ \\
\hline 36 & Pongamia pinnata & $\mathrm{T}$ & M \\
\hline 37 & Averrhoea carambola & S & M \\
\hline 38 & Curculigo orchioidos & $\mathrm{H}$ & M \\
\hline 39 & Citrus medica & $\mathrm{T}$ & M \\
\hline 40 & Vitex altissima & S & M \\
\hline 41 & Cocos nucifera & $\mathrm{T}$ & M \\
\hline 42 & Piper longum & S & M \\
\hline
\end{tabular}

H-High $\quad$ M-Medium L- Low
Fauna

During the present survey 28 species of avifauna were recorded (Table 6). The highest index of diversity was recorded at Usgaon village. Based on data collected by the authors' faunal elements found in the region are presented in Table 7. The faunal elements listed in Table 7 are categorized as per Schedule I to IV based on Wild Life Protection Act 1972 and subsequent amendments.

\section{DISCUSSIONS}

The floristic structure and species composition in forestland is mainly dominated by Bischofia, Macranga, Hoppea sp. The nature of vegetation cover is mixed, dry, and uneven-aged stands with uneven distribution of Phoenix sylvestris, Anacardium occidentale, Cocos nucifera, Pteris spp, Borassus flabellifer, Cassia sp, and Caesalpinia sp. Most of the human population is dependent on agriculture for their livelihood. The grazing on uninhabited wasteland by livestock is a common practice because of more number of cattle and openly available land for grazing.

Few medicinal and economically important plants Salacia chinensis, Rubia cordifolia, Spillanthus paniculata, hollarhena antidysenterica, Tylophora indica, Hemidesmus indicus, Withania somnifera, Curculigo orchioides, Gloriosa superba, Asperagus racemosus, Strychnos nux-vomeca, Gymnema sylvestre, etc. and Anacardium, Mangifera, Ananus, Areca, Piper, Artocarpus, Garcinia, Myristica, Murraya, Citrus, Flacourtia, Averrhoea, etc. were recorded. Regeneration of trees is poor as compared to herbs and shrubs in the study area except for Cassias and Caesalpinias.

The density and composition of vegetation hardly change with a change in locations. Grasses and herbs mainly cover open land. Herbs and shrubs are abundant only during monsoon, whereas during rest of the year when the land turns dry, herbs wither and get wiped away from the vicinity. The ground vegetation is composed by seasonal herbs (annual/biennial) with some perennial forms, accounting to 8 species i.e. Grewia asiatica, Cassia tora, Tridax, Aerva, Cyperus, Amaranthus, Achyranthus, Aegeratum etc. The reduction in vegetation cover is attributed to biotic pressures like fuelwood, livestock grazing, clearing for industrial setup, agriculture, human habitation, loss of fertility, erosion, salinity ingression etc.

The vegetation type is subtropical coastal thorny scrub jungles with trees predominantly moist deciduous type but rarely evergreen. The natural vegetation is scarce, scattered and open. The reserve forest is found only at Gangem. In all other areas, the trees are dominated by Grewia spp, Woodfordia spp. The forest falls under two major categories like a open Scrub jungle and moist deciduous forests. The forest near Valpoi fall under this category and much of the Goa forest fall under this category. 
The major components of the moist deciduous forest are the species belong to the families like Rubiaceae, Bignoniaceae, Anacardiaceae, Sapindaceae, Fabaceae, Caesalpiniaceae, and Mimosaceae. The ground flora also contains species of Pteris, Sellaginella, etc. The tree components of this forest are belonging to the families like Clusiaceae, Ebenaceae, Fabaceae, Moraceae, Combretaceae, Euphorbiaceae, and Rutaceae. The tallest and largest trees are belong to the species of Michelia, Cryptocarya, Actinodaphne, Ficus, Lagerstroemia, etc. the shrubby species are Ixora, Calophyllum, Garcinia, Canarium, Artocarpus, Mallotus, Bischofia, Macranga, Hoppea, etc.

An average density of plants in Study area is 205 trees, 127 shrubs and 272 herbs/ha in an average noted on the 16 survey locations in the study area. A total of 3280 trees, 2032 shrubs and 4352 herbs were examined in the entire plot area of $1600 \times 1600$ sq. m. for tree, 320 x 320 sq. m. for shrub, and 80 x 80 sq. m. for herbs. Dominant tree species listed are Terminalia crenulata, Terminalia bellerica, Pterocarpus Marsupium, Borassus flabellifer, Anacardium Occidentale, Cocos nucifera and Phoenix sylvestris. Most dominant shrubs are Calotropis procera, Alangis lamarokki, Kaeampfria rotunda, Crossandra unduliformis, Adhatoda vasica etc. and in case of herbs Withania somnifera, Indigefera tinctoria, Hiptage benghalensis, Vetiveria indica, and Cymbopogon citratus are dominant

The common herbal medicinal flora of the study area consists of Crossandra undulifolia, Adhatoda vasica, Spillanthus acmella, Acacia arabica, Cassia fistula, Morinda citrifolia, Terminalia bellerica, Aegle marmelos, Ocimum basilicum, Holarrhena antidysenterica, and Withania somnifera.

The faunal species have been categorized in Schedules I, II, III, IV and V as per the Wild Life Protection Act, 1972. In general, the rarest, endangered and almost extinct species are classified under Schedule I. The Department of Forests periodically reviews the list and is empowered to shift the species to any other schedule depending upon rarity of the species. According to Wild Life Protection Act 1972 hunting of animals in Schedule I is prohibited and as per amendment (1991) made to this act none of the animals mentioned in Schedule I to IV can be hunted.

\section{CONCLUSIONS}

After the collection of baseline data and subsequent identification and possible impact, the following environmental impact statement have been prepared for Biological component which is likely to be affected or benefited due to growing pharma units in the area.

The Simpson's Diversity Index for herb, shrub and trees is shown that the area has low diversity of herbs $(0.025)>$ shrubs $>(0.116)>$ trees $(0.176)$. The percentage of medicinal plant species for particularly these observations is about $45 \%$.

Regeneration of trees is poor as compared to herbs and shrubs in the study area except for Cassias and Caesalpinias. Average density of plants in Study area is 205 trees, 127 shrubs and 272 herbs / ha in an average noted on the 16 survey locations in the study area.

During the present survey 28 species of avifauna were recorded. The highest index of diversity was recorded at Usgaon village. In general, the Rare, Endangered and Almost extinct species are classified under Schedule I. Only two species of Mammals ie. Lepus nigricollis, Canis lupus and one species from Reptiles ie. Python molurus noted in Schedule I.

Most of the reserved forest area is on the West and South of the Pharma Industries zone. South-east and East being the most prevalent wind direction, thus, no adverse impact on reserve forest is predicted. The liquid wastes to be generated during processing is being treated by conventional method so as to meet the stipulated standards. The resultant effluent, after discharge in receiving water body, will not have any adverse impact on aquatic ecology.

There is no negative impact observed on the existing natural vegetation and there will not be the change in the existing biodiversity due to pharmaceutical industry in GIDC zone. The wind flow pattern is in opposite direction of the Bondla wild life century. Thus, Wild life is not at all affected air and noise pollution provided there must be scientifically developed Greenbelts. India has a list of threatened species published in Red Data Book by the Botanical Survey of India and Zoological survey of India. No species enlisted in present survey are recorded in Red Data Book as threatened, rare or endangered.

\section{Green Belt Development}

As the GIDC is surrounded by lush green forest area along with Bondla Wildlife Sanctuary region. But it is observed that Southeast region of the industrial zone is almost barren. Therefore, it is recommended that green belt should be develop on the basis that it should absorbs air pollutants, fast growing, thick canopy, perennial and ever green and large leaf area index.

\section{ACKNOWLEDGEMENTS}

We thank The Merck Ltd., Marvasodo, Usgaon, Ponda (Goa) for providing fund to cover expenses of the study. We are grateful to the Sadekar Enviroteck Private limited, Goa, for the supply of a field vehicle. We also thank the Principal, Shri Chhatrapati Shivaji College, Omerga for allowing us to carry out this study. We are grateful to administrative officials at zonal and district levels in the study area. 
Table 6

Dominance and diversity of Common Birds

\begin{tabular}{|c|l|l|l|c|c|c|}
\hline $\begin{array}{c}\text { Sr. } \\
\text { No. }\end{array}$ & Location & \multicolumn{1}{|c|}{$\begin{array}{c}\text { Most Dominant } \\
\text { Species }\end{array}$} & $\begin{array}{c}\text { Diversity } \\
\text { Index }\end{array}$ & $\begin{array}{c}\text { Dominance } \\
\text { Index }\end{array}$ & $\begin{array}{c}\text { Species } \\
\text { Richness }\end{array}$ & $\begin{array}{c}\text { Total } \\
\text { Density } \\
\left(\mathrm{Km}^{-2}\right)\end{array}$ \\
\hline 1. & Bondla & Little egret & 1.86 & 40.54 & 9 & 185.00 \\
\hline 2. & Candepar & Common myna & 2.05 & 25.00 & 10 & 200.00 \\
\hline 3. & Usgaon & House crow & 1.36 & 35.00 & 6 & 100.00 \\
\hline 4. & Peliem & Blue rock pigeon & 2.00 & 30.31 & 8 & 82.50 \\
\hline 5. & Codar & House swift & 1.60 & 43.48 & 6 & 57.50 \\
\hline 6. & Vaghurmem & House sparrow & 1.17 & 76.93 & 4 & 32.50 \\
\hline 7. & Palle & Blackwinged stilt & 2.01 & 58.35 & 6 & 30.00 \\
\hline 8. & Cothambi & House sparrow & 1.00 & 77.78 & 5 & 135.00 \\
\hline 9. & Paikul & Little egret & 1.60 & 31.25 & 8 & 200.00 \\
\hline
\end{tabular}

Table 7

Faunal Elements in the Region

\begin{tabular}{|r|l|l|l|l|r|}
\hline Sr. No. & Name & Zoological Name & Family & Feeding status & $\begin{array}{c}\text { Status in Wildlife } \\
\text { Protection Act-1972 }\end{array}$ \\
\hline & Mammals & & & & \\
\hline 1 & Langur & Presbytis entellus & Cercopithecidae & Herbivore & Sch-II \\
\hline 2 & Hare & Lepus nigricollis & Leporidae & Herbivore & Sch-I \\
\hline 3 & Squirrel & Funambulus sp. & Sciuridae & Herbivore & - \\
\hline 4 & Wild Boar & Sus scrofa & Suidae & Omnivore & Sch-III \\
\hline 5 & Wild Dog & Cuon alpinus & Canidae & Carnivore & Sch-II \\
\hline 6 & Wolf & Canis lupus & Canidae & Carnivore & Sch-I \\
\hline 7 & Jackal & Canis aurcus & Canidae & Carnivore & Sch-II \\
\hline & Snakes & & & & Carnivore \\
\hline 8 & Python & Python molurus & Boidae & Sch-I \\
\hline 9 & Indian Cobra & Naja naja & Elapidae & Carnivore & Sch-II \\
\hline 10 & Pit Viper & & Crotalidae & Carnivore & Sch-IV \\
\hline 11 & Krait & Bungarus candidus & Elapidae & Carnivore & Sch-IV \\
\hline
\end{tabular}

\section{REFERENCES}

Almeida, S M, 1990. Flora of Sawantwadi, Maharashtra, India. J. Econ. Tax. Bot. Addl. Ser. Vol.2.

Central Pollution Control Board (Pollution Control Acts, Rules and Notification), Vol-I, 1998, Ministry of Environmental and Forests, Govt. of India, New Delhi.

Clements, E S, 1960. Adventures in Ecology. Hafner Publishing Company. ISBN 9780028429304

Clifford H T and Stephenson W, 1975. An introduction to numerical classification. London: Academic Express. Cited in Magurran, A E, 2004. Measuring biological diversity, Blackwell Publishing: Oxford, UK.256 p

Cowan, E C, D J Versteeg, R J Larson and P J Kloepper-Sams, 1995. Integrated approach for environmental assessment of new and existing substances. Regul. Toxicol Pharmacol.. 21:3-31. https://oi.org/10.1006/rtph.1995.1003
EMEA. Guidelines on Environmental Impact Assessment (EIAs) for Veterinary Medicinal Products (VMPs) -. Phase I. CVMP/VICH/592/98 FINAL, 20 July 2000 [VICH GL6 (ECOTOXICITY PHASE I), June 2000] Brussels: European Agency for the Evaluation of Medicinal Products, Committee on Veterinary Medicinal Products, 2000.

FAO Soils Bulletin, Soil and plant testing as a basis of fertilizer, 38/2, Rome 1980 .

Haling-Sorensen B, Nors Nielson S, Lanzky P F, Ingerslev F, Holten Lutzhoft H C, Jergensen S E, 1998. Occurrence, fate and effects of pharmaceutical substances in the environment-a review. Chemosphere 36 (2): 357-393 https://doi.org/10.1016/S0045-6535(97)00354-8

Magurran, A E, 2004. Measuring biological diversity, Blackwell Publishing: Oxford, UK.256 p

Saepen K R I, Van Leemput L J I, Wislocki P G, Verschueren C, 1997. A uniform procedure to estimate the predicted environmental concentration of the residues of veterinary medicines in soil. Environ Toxicol Chem 16:1977-1982 https://doi.org/10.1002/etc.5620160930 
Shannon, C E, 1948. A mathematical theory of communication. The Bell System Technical Journal, 27, 379-423 and 623-656. 10.1002/j.15387305.1948.tb00917.x

Simpson, E H, 1949. "Measurement of diversity". Nature. 163: 688. doi:10.1038/163688a0

Stimson, R P, 1993. Pharmaceutical Waste: Liability, Drugs, Brokers, Ethics and Politics, Part I. Pharmaceutical Technology. Pp. 84-87.

U. S. EPA, October 1991. Guides to Pollution Prevention: The Pharmaceutical Industry. EPA/ 625/7-91/017.

U. S. FDA. Environmental Assessment Technical Assistance Handbook. Washington, DC:U.S. Food and Drug Administration, 1987.

U. S. FDA. Retrospective Review of Eco-toxicity Data. Submitted in Environmental Assessment for Public Display. Docked no. 96N-0057 Washington, DC: U.S. Food and Drug Administration, 1997.

Venkataramani, E S, 1994. Pollution Prevention in the Pharmaceutical Industry. Industrial Pollution Prevention Handbook, H. M. Freeman, Ed. New York: McGraw-Hill. Pp .865-883.

Venkataramani, E S, 1990. Waste Minimization in a Leading Ethical Pharmaceutical Company. Environmental Progress. Vol. 9, No. 3 pp. AloAll. https://doi.org/10.1002/ep.670090311

WPI: http://www.pharmaceutical-drug-manufacturers.com

WP2: http://www.goaidc.com

WP3: Kumar Pramod and Sudhir Sharan, 2013. Marketing Mix of Pharmaceutical Industry in India: An Exploration published on ResearchGate:

https:/www.researchgate.net/publication/272376646 Marketing Mix of Pharmaceutical Industry in India An Exploration

WP4: http://theviewspaper.net/the-indian-pharmaceuticals/

WP5: https://educheer.com/indian-pharmaceutical-industry-companiesmarket-india/

( 2018 | Published by Plantae Scientia 